\title{
PENINGKATAN KEMAMPUAN GURU DALAM MEMBUAT RENCANA PELAKSANAAN PEMBELAJARAN (RPP) TEMATIK 1 HALAMAN MELALUI WORKSHOP DARING DENGAN VARIASI MODEL JIGSAW DI UNIT PELAKSANA TEKNIS DAERAH (UPTD) SEKOLAH DASAR (SD) NEGERI GENTENG 2 BANGKALAN
}

\author{
Zainal Arifin \\ Kepala UPTD SD Negeri Genteng 2 \\ Email: zainal771@yahoo.co.id
}

\begin{abstract}
Abstrak
Penelitian ini merupakan penelitian tindakan sekolah dengan instrument utama tugas pembuatan Rencana Pelaksanaan Pembelajaran (RPP) tematik 1 halaman. Terdapat 2 siklus pembinaan dan hasil penelitian menunjukkan bahwa kemampuan guru dalam membuat Rencana Pelaksanaan Pembelajaran (RPP) tematik 1 halaman dapat ditingkatkan melalui workshop daring dengan variasi model jigsaw. Hal ini dibuktikan dalam pelaksanaan penelitian tindakan sekolah yang terdiri dari 2 siklus menunjukkan adanya kenaikan dari siklus I ke siklus II berdasarkan hasil penugasan yang dilakukan dalam pembuatan RPP tematik, yaitu dari 7 guru terdapat 3 guru atau 42,86\% berkategori rendah, masing-masing 2 guru atau 28,57\% berkategori sedang dan tinggi. Setelah dilaksanakan siklus II diperoleh data kemampuan guru dalam membuat RPP tematik 1 halaman sebagai berikut bahwa tidak terdapat guru yang berkategori rendah, 1 guru atau 14,28\% berkategori sedang, dan 6 guru atau 85,71\% berkategori tinggi, oleh sebab itu siklus dihentikan, sebab sudah mencapai indikator keberhasilan yang diharapkan, yaitu melebihi 75\% berkategori tinggi. Hendaknya bapak dan ibu guru terus meningkatkan kompetensinya dalam membuat RPP Tematik 1 halaman.
\end{abstract}

Kata kunci: Kemampuan guru, Workshop daring, model jigsaw.

\begin{abstract}
This research is a school action research with the main instrument being the task of making 1-page thematic lesson plans. There are 2 coaching cycles and the results of the study show that the teacher's ability to make 1-page thematic lesson plans can be improved through online workshops with variations of the jigsaw model. This is evidenced in the implementation of school action research which consists of 2 cycles showing an increase from cycle I to cycle II based on the results of assignments carried out in making thematic lesson plans, namely from 7 teachers there are 3 teachers or $42.86 \%$ in the low category, every 2 teachers or $28.57 \%$ in the medium and high categories. After the second cycle was carried out, the data obtained from the teacher's ability to make 1-page thematic lesson plans as follows that there were no teachers in the low category, 1 teacher or $14.28 \%$ in the medium category, and 6 teachers or $85.71 \%$ in the high category, therefore the cycle was stopped, because it has reached the expected success indicator, which is more than $75 \%$ in the high category. Teachers should continue to improve their competence in making 1-page Thematic lesson plan.
\end{abstract}

Keywords: Teacher skills, online workshops, jigsaw models. 


\section{PENDAHULUAN}

Pendidikan merupakan suatu upaya dan usaha untuk membelajarkan peserta didik menjadi pribadi yang memiliki kecerdasan, sehingga memiliki wawasan yang luas berbuat dan bertindak sebagaimana tuntunan nilai-nilai agama dan nilai-nilai luhur. Mengembangkan potensi peserta didik sudah dimulai sedini mungkin sehingga kelak menjadi pribadi yang tangguh cerdas intelektual dan cerdas secara emosional. Dalam mengembangkan kemampuan dan membentuk watak peserta didik tidak terlepas dari peranan guru sebagai tenaga pendidik.

Salah satu peranan guru dalam pendidikan adalah sebagai perencana proses pembelajaran, menurut James W. Brown dalam Sardiman mengemukakan bahwa tugas dan peranan guru adalah menguasai dan mengembangkan materi pelajaran, merencanakan dan mempersiapkan pelajaran sehari-hari, mengontrol dan mengevaluasi kegiatan siswa. Dalam merencanakan proses pembelajaran guru harus memiliki dasar pengetahuan yang luas sehingga pembelajaran menjadi berkualitas dan potensi peserta didik dapat ditingkatkan secara berkesinambungan. ${ }^{1}$

Dalam perubahan kurikulum pendidikan nasional dari KTSP (Kurikulum Tingkat Satuan Pendidikan) tahun 2006 ke Kurikulum tahun 2013 atau biasa disebut dengan K13, pemerintah baik dari Kementerian Pendidikan Nasional maupun dari Kementeria Agama telah memberikan pelatihan terhadap para guru dalam rangka memberikan pemahaman terhadap K-13. Para pendidik di berbagai sekolah digodok untuk memperisiapkan diri memasuki era pembelajaran baru dengan scientific approach. Arinya para personalia dan sumber daya manusia sekolah diutamakan dalam pelatihan tersebut guna mencapai tujuan nasional pendidikan Indonesia. ${ }^{2}$

Pelaksanaan kurikulum 2013 menjadi program pendidikan saat ini meskipun sempat dihentikan untuk kembali ke KTSP, kecuali bagi satuan pendidikan yang sudah melaksanakannya sesuai dengan imbauan menteri pendidikan melalui Permendikbud Nomor 160 Tahun 2014 tentang Pemberlakuan kurikulum tahun 2006 dan kurikulum 2013. Pemberdayaan pengawas untuk mengetahui, memahami, serta mampu mengaplikasikan dengan memberikan bimbingan dan pendampingan secara langsung pada guru juga dilakukan agar kurikulum 2013 dapat berjalan dengan baik khususnya pada kelas II dan kelas IV.

Di sisi lain tuntutan untuk meningkatkan kualitas pembelajaran bagi guru juga terus ditingkatkan melalui program guru pembelajar. Hal ini disebabkan hasil rata-rata Uji Kompetensi Guru rendah. Semua guru pada jenjang pendidikan dasar dan menengah diharuskan terus meningkatkan kompetensinya. Dengan kegiatan ini secara langsung guru disibukkan dengan berbagai program pengembangan.

Menindaklanjuti salah satu misi "merdeka belajar" pada surat edaran no 14 Tahun 2019, tentang pidato Mendikbud Nadiem Makarim mengenai pendidikan, bahwa penyusunan/perumusan Rencana Pelaksanaan Pembelajaran (RPP) dibuat dengan prinsip efesien, efektif yang harus berorientasi pada siswa. Inti dari pidato nadiem adalah berupa "Ajakan memerdekakan diri dalam dunia pendidikan. Dan pidato tersebut bisa sebagai

\footnotetext{
${ }^{1}$ Sardiman, Interaksi Dan Motivasi Belajar Mengajar (Jakarta: Rajawali Pers, 2014), 144.

${ }^{2}$ Hilmi Qosim Mubah, "PSIKOMANAJERIAL PERSONALIA PENDIDIKAN; MENGKONSTRUKSI PRODUKTIVITAS KERJA PERSPREKTIF IDENTIFIKASI KEMATANGAN PERSONAL," $A L$ FIKRAH: Jurnal Studi Ilmu Pendidikan Dan Keislaman 2, no. 2 (2019): 11, https://www.jurnal.alhamidiyah.ac.id/index.php/al-fikrah/article/view/57.
} 
penyegar untuk para guru yang menginginkan kemudahan administrasi. Contoh penyegar pidato Mendikbud tersebut adalah penyederhanaan salah satu administrasi guru yaitu Rencana Pelaksanaan Pembelajaran (RPP). Penyederhannan Rencana Pelaksanaan Pembelajaran (RPP) tersebut juga untuk jenjang pendidikan pertama dan menengah.

Kemudian untuk Sekolah, Kelompok Kerja Guru (KKG) mata pelajaran sejenis dalam sekolah, dan individu guru bebas memilih, membuat mengembangkan dan menggunakan format Rencana Pelaksanaan Pembelajaran (RPP) secara mandiri untuk keberhasilan proses belajar murid. Pokok-pokok materi Rencana Pelaksanaan Pembelajaran (RPP) juga ada tiga (3) komponen yaitu tujuan Pembelajaran, langkahlangkah (kegiatan) pembelajaran, penilaian pembelajaran (Assessment). ${ }^{3}$

Penyusunan Rencana Pelaksanaan Pembelajaran (RPP) menjadi 3 yaitu efektif, efesien dan berorientasi/fokus pada murid. Maka Rencana Pelaksanaan Pembelajaran (RPP) satu lembar lebih sesuai dengan model pembelajaran yang kita inginkan. Adapun mengenai muatan yang terdapat dalam Silabus tidak ada perubahan. Sesuai Surat Edaran Mendikbud Nadiem Makarim No 14 Tahun 2019, maka Rencana Pelaksanaan Pembelajaran (RPP) satu Halaman/Lembar Sekolah Dasar bertujuan agar para guru dapat leluasa untuk memilih Kompetensi Dasar (KD) dan muatan mata pelajaran. Namun, semua harus tetap mengacu pada Silabus.

Kebijakan Rencana Pelaksanaan Pembelajaran (RPP) 1 halaman merupakan upaya penyederhanaan skenario pembelajaran yang dibuat oleh guru sebelumnya yang isinya banyak lembar, jika dihitung lembaran mulai dari identitas sampai dengan rubrik penilaian boleh jadi lebih dari 10 lembar. Hal inilah yang dianggap terlalu memberatkan guru dalam mempersiapkannya. Untuk itu penyederhanaan dilakukan dengan hanya mencantumkan tujuan pembelajaran, langkah-langkah pembelajaran dan penilaian, dari sebelumnya mencantumkan identitas sekolah, identitas mata pelajaran, KI dan KD, indikator, tujuan pembelajaran, materi, metode pembelajaran, media dan sumber belajar, langkah-langkah pembelajaran, penilaian hingga lengkap dengan rubriknya; bahkan juga diperlukan lampiran rubrik penilaian dan bahan ajar. ${ }^{4}$

Sedangkan penjelasan teknik mengajar jigsaw penulis megambil apa yang telah dikembangkan oleh Aroson sebagai metode Coopertaive Learning. Lie mengemukakan bahwa metode jigsaw adalah suatu metode kooperatif yang memperhatikan skemata atau latar belakang pengalaman siswa dan membantu mengaktifkan skemata tersebut agar bahan pelajaran lebih bermakna. ${ }^{5}$ Jigsaw learning atau pembelajaran tipe Jigsaw merupakan sebuah teknik yang dipakai secara luas yang memiliki kesamaan dengan teknik pertukaran dari kelompok ke kelompok (grup-to-grup exchange) dengan suatu perbedaan penting yaitu setiap peserta didik mengajarkan sesuatu. Dalam teknik ini peserta didik belajar dengan sebuah kelompoknya, di mana dalam kelompok tersebut terdapat satu orang ahli yang membahas materi tertentu. ${ }^{6}$

\footnotetext{
3 Abu Mashud, "RPP Satu Halaman/Lembar SD/MI Kelas 1,2,3,4,5 Dan 6," Artikel online, 2020, https://dewanguru.com/2020/01/22/rpp-satu-halaman-lembar-sd-mi-kelas-12345-dan-6/.

${ }^{4}$ Wahidmurni, "RENCANA PELAKSANAAN PEMBELAJARAN: RPP 1 LEMBAR" (Malang, 2019), http://repository.uin-malang.ac.id/5377/1/5377.pdf.

5 Anita Lie, Cooperative Learning:Mempraktikkan Cooperative Learning Di Ruang-Ruang Kelas. (Jakarta: Gramedia Widiasarana Indonesia, 2008), 69.

${ }^{6}$ Melvin L. Silberman, Active Learning 101 Stategi Pembelajarn Aktif (Yogyakarta: Yappendis, 2002), 168.
} 
Metode jigsaw adalah salah satu tipe pembelajaran aktif yang terdiri dari tim-tim belajar heterogen beranggotakan 4-5 orang (materi disajikan peserta didik dalam bentuk teks) dan setiap peserta didik bertanggung jawab atas penguasaan bagian materi belajar dan mampu mengajarkan bagian tersebut kepada anggota lain. Metode jigsaw telah dikembangkan dan diuji coba oleh Elliot Aronson dan teman-teman di Universitas Texas, dan teman-teman di Universitas John Hopkins pada tahun 1978. Jigsaw merupakan model pembelajaran kooperatif, dengan siswa belajar dalam kelompok kecil yang terdiri dari 46 orang secara heterogen.

Kompetensi guru Unit Pelaksana Teknis Daerah Sekolah Dasar Negeri Genteng 2 dalam membuat dan mengembangkan Rencana Pelaksanaan Pembelajaran (RPP) 1 halaman ini menunjukkan beberapa permasalahan diantaranya guru belum mengetahui bentuk Rencana Pelaksanaan Pembelajaran (RPP) 1 halaman khususnya dalam pendekatan tematik, dan belum paham tentang metode pembelajaran saintifik pada kurikulum 2013. Bentuk penilaian juga belum dikuasai secara maksimal, bahkan ada beberapa guru yang mana ketika dilakukan supervisi terdapat guru belum membuat rencana pelaksanaaan pembelajaran. ${ }^{7}$

Sebagai seorang kepala Unit Pelaksana Teknis Daerah (UPTD) Sekolah Dasar (SD) Negeri Genteng 2 mempunyai tanggung jawab yang besar untuk menyelesaikan segala permasalahan yang ada, baik yang datang dari dalam lembaga maupun dari luar. Di UPTD SD Negeri Genteng 2 terdiri dari 7 guru yang rata-rata kemampuan penguasaan dalam membuat Rencana Pelaksanaan Pembelajaran (RPP) juga masih rendah. Meskipun ada guru yang memiliki kemampuan dalam membuat Rencana Pelaksanaan Pembelajaran (RPP) disebabkan sering mengikuti pelatihan dan berupaya terus mengembangkan diri. ${ }^{8}$

Pendampingan sebagai upaya pembinaan sebagai unsur penting dalam peningkatan disiplin dan kinerja guru. ${ }^{9}$ Sebagai seorang kepala sekolah harus terus melakukan pembinaan dan pengembangan kompetensi guru berdasarkan supervisi yang telah dilaksanakan. Setiap kali dilakukan supervisi baik akademik maupun manajerial saat itu selalu ditemukan berbagai permasalahan yang dihadapi para guru dan kepala sekolah.

Bertugas sebagai seorang kepala sekolah mempunyai rasa tanggung jawab besar untuk menyelesaikan permasalahan ini melalui upaya pembinaan dengan mendorong para guru di setiap lembaga untuk melaksanaan proses pembelajaran dengan didahului persiapan pelaksanaan pembelajaran yang sesuai dengan tuntutan Permendikbud Nomor 22 Tahun 2016 Tentang Standar Proses Pendidikan Dasar dan Menengah.

Pembinaan dapat dilakukan dengan kegiatan workshop daring yang dapat mengaktifkan para guru. Misalnya divariasikan dengan model Jigsaw. Model ini diadopsi dari model pembelajaran siswa. Lie dalam Haryanto ${ }^{10}$ menyatakan pembelajaran kooperatif model jigsaw ini merupakan model belajar kooperatif dengan cara siswa belajar dalam kelompok kecil yang terdiri atas empat sampai dengan enam orang secara

\footnotetext{
${ }^{7}$ Hasil observasi, supervisi Maret 2021

8 Ibid.

${ }^{9}$ Harsono, "Upaya Meningkatkan Kemampuan Guru Dalam Penggunaan Teknologi Informasi Dan Komunikasi (TIK) Untuk Pembelajaran Melalui Workshop Dengan Variasi Model Jigsaw Di Guslah 3 Kecamatan Konang Kabupaten Bangkalan,” Penelitian Tindakan Sekolah Pengawas UPTD Konang Kabupaten Bangkalan. (Bangkalan, 2015).

${ }^{10}$ Haryanto, "Model Pembelajaran Kooperatif Tipe Jigsaw," Makalah (Online), 2012, http://belajarpsikologi.com/model-pembelajaran-kooperatif-jigsaw.
} 
heterogen dan siswa bekerja sama saling ketergantungan positif dan bertanggung jawab secara mandiri.

Ruang lingkup penelitian ini adalah penguasaan kemampuan guru dalam membuat Rencana Pelaksanaan Pembelajaran (RPP) tematik 1 halaman untuk pembelajaran. Pelaksanaan workshop daring ini difokuskan pada 7 guru baik yang berstatus Pegawai Negeri Sipil (PNS) maupun non PNS, guru-guru tersebut adalah Moh. Naruddin, Riski Fitria Y., Eka Purwatiningsih, Hendra Prata, M. Syukkur, Khoiriyah, dan Erlin Handayani. Dari 7 guru tersebut hanya diambil masing-masing sekolah 3 guru berstatus PNS dan 4 guru lainnya berstatus non PNS. Dan dari 7 orang guru tersebut, telah ada 1 orang guru yang sudah mahir dalam membuat Rencana Pelaksanaan Pembelajaran (RPP) tematik 1 halaman sehingga dapat membantu penulis dalam pembinaan daring ini.

Setiap penelitian memiliki variabel atau fokusnya. Variabel adalah suatu atribut, sifat, aspek dari manusia, gejala, objek yang mempunyai variasi tertentu yang ditetapkan oleh peneliti sehingga terukur untuk dipelajari dan diambil kesimpulannya. ${ }^{11}$ Penelitian tindakan sekolah ini terdapat dua fokus atau variabel, yaitu kemampuan membuat Rencana Pelaksanaan Pembelajaran (RPP) tematik bagi guru dan workshop variasi model jigsaw.

Kemampuan guru dalam membuat Rencana Pelaksanaan Pembelajaran (RPP) 1 halaman yang dimaksud pada penelitian ini adalah kemampuan guru dalam membuat Rencana Pelaksanaan Pembelajaran (RPP) tematik 1 halaman sesuai tuntutan yang terbaru didasarkan permendikbud Nomor 22 tahun 2016 tentang Standar Proses Pendidikan Dasar dan Menengah dan didasarkan pada Surat Edaran Mendikbud Ndiem Makarim No 14 Tahun 2019.

Hasil penelitian terdahulu juga menunjukkan bahwa workshop dapat mengaktifkan para guru di Guslah 3 Kecamatan Konang dalam penguasaan kemampuan menguasai penggunaan teknologi informasi. ${ }^{12}$ Oleh sebab itu sebagai upaya mengatasi permasalahan rendahnya kemampuan guru di UPTD SDN Genteng 2 dalam membuat Rencana Pelaksanaan Pembelajaran (RPP) Tematik 1 halaman, dilakukan penelitian tindakan sekolah dengan judul: Peningkatan Kemampuan Guru Dalam Membuat Rencana Pelaksanaan Pembelajaran (RPP) Tematik 1 Halaman Melalui Workshop Daring Dengan Variasi Model Jigsaw di Unit Pelaksana Teknis Daerah (UPTD) Sekolah Dasar (SD) Negeri Genteng 2.

\section{METODE PENELITIAN}

Penelitian ini menggunakan desain penelitian tindakan sekolah (PTS) Pada setiap siklus mencakup perencanaan, pelaksanaan tindakan, pengamatan, dan refleksi. Siklus akan berhenti ketika sudah terjadi peningkatan kemampuan penguasaan pembuatan Rencana Pelaksanaan Pembelajaran (RPP) tematik 1 halaman bagi guru di UPTS SD Negeri Genteng 2 Kecamatan Konang Kabupaten Bangkalan.

Penelitian Tindakan Sekolah merupakan penelitian yang dilakukan oleh Kepala Sekolah atau Pengawas Sekolah. Fokus penelitian yang dilakukan oleh Kepala Sekolah sekitar supervisi klinis, menyangkut aspek akademik seperti proses pembelajaran yang

\footnotetext{
${ }^{11}$ Hamid Darmadi, Metode Penelitian Pendidikan (Bandung: Alfabeta, 2011), 21.

${ }^{12}$ Harsono, "Upaya Meningkatkan Kemampuan Guru Dalam Penggunaan Teknologi Informasi Dan Komunikasi (TIK) Untuk Pembelajaran Melalui Workshop Dengan Variasi Model Jigsaw Di Guslah 3 Kecamatan Konang Kabupaten Bangkalan.”
} 
diselenggarakan oleh guru-guru. Meningkatkan kemampuan guru dalam membuat Kriteria Ketuntasan Minimal, RPP, silabus, dan penilaian hasil belajar siswa dan lainlain. PTS dapat diartikan sebagai sebuah penelitian tindakan, atas hal-hal yang ada dalam ruang lingkup pendidikan di sekolah, sifatnya memerlukan tindakan segera, dilakukan oleh Kepala Sekolah atau Pengawas Sekolah secara berulang-ulang melalui langkahlangkah, yaitu membuat perencanaan (plan), melaksanakan (action), observasi (observation), dan refleksi (reflection), sampai pada batas keadaan yang telah ditentukan. ${ }^{13}$

Adapun secara garis besar gambaran siklus tersebut dalam desain penelitian ini akan terlihat sebagaimana alur penelitian tindakan sekolah. Pelaksanaan Penelitian Tindakan Sekolah, dimulai dengan siklus yang pertama yang terdiri dari empat kegiatan. Apabila sudah diketahui letak keberhasilan dan hambatan dari tindakan yang dilaksanakan pada siklus pertama tersebut, guru bersama peneliti (dalam kasus ini bersama dengan pengawas sekolah) menentukan rancangan untuk siklus kedua.

Setiap siklus dalam penelitian tindakan sekolah mengikuti tahapan seperti dalam penelitian tindakan kelas. Tahapan kegiatan dalam setiap siklus meliputi perencanaan, pelaksanaan, observasi, dan refleksi. Pelaksanaan refleksi sebagai penentu apakah siklus dilanjutkan atau diberhentikan. Siklus dilanjutkan bila belum sesuai dengan harapan. Sedangkan siklus dihentikan jika sudah sesuai dengan harapan. Adapun tahapan alur penelitian tindakan sekolah dapat digambarkan sebagai berikut.

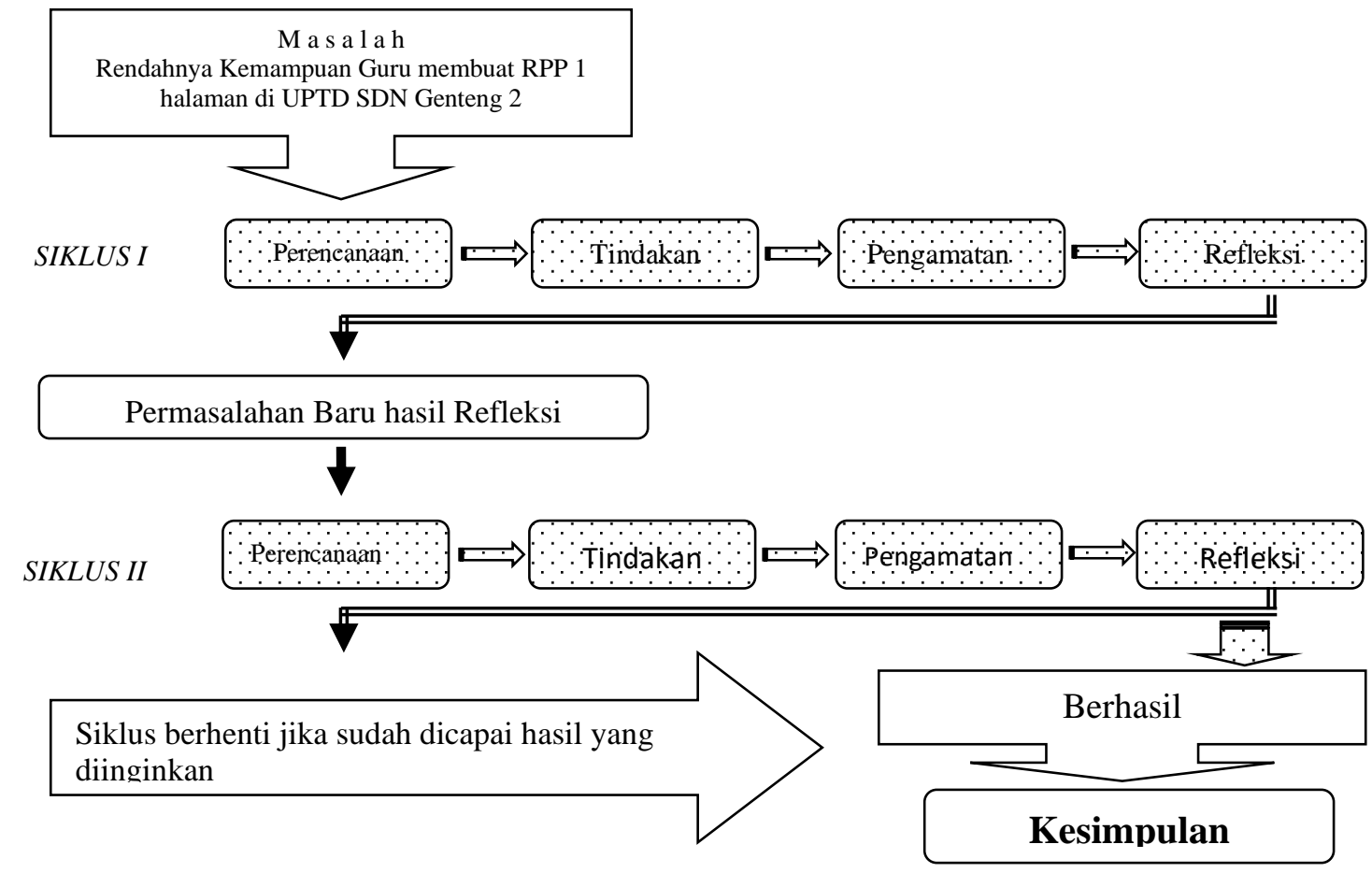

\footnotetext{
${ }^{13}$ Mohammad Yusuf, "PENINGKATAN KEMAMPUAN GURU DALAM MENENTUKAN KRITERIA KETUNTASAN MINIMAL (KKM) MELALUI WORKSHOP DI UPTD SDN BANDA SOLEH 1 KECAMATAN KOKOP KABUPATEN BANGKALAN TAHUN 2019," Re-JIEM (Research Journal of Islamic Education Management) 2, no. 1 (2019): 138, https://doi.org/https://doi.org/10.19105/rejiem.v2i1.2456.
} 
Pelaksanaan tindakan dengan menerapkan workshop variasi model jigsaw oleh peneliti sebagai Kepala Sekolah UPTD SD Negeri Genteng 2. Kegiatannya diawali dengan perencanaan dengan berkoordinasi dengan seluruh guru yang ada di UPTD SDN Genteng 2. Penentuan hari serta materi kemampuan membuat Rencana Pelaksanaan Pembelajaran (RPP) tematik 1 halaman bagi guru juga direncanakan. Setelah tersusun rencana dilakukan tindakan dengan workshop daring variasi model jigsaw. Hasilnya dilakukan pengamatan serta refleksi. Kegiatan refleksi dilakukan dengan mengevaluasi hasil pelaksanaan workshop daring variasi model jigsaw terhadap kemampuan guru dalam membuat Rencana Pelaksanaan Pembelajaran (RPP) tematik 1 lembar di UPTD SD Negeri Genteng 2. Dalam kegiatan ini semua guru UPTD SD Negeri Genteng 2 dilibatkan untuk merefleksi dan memberikan masukan-masukan.

Subjek penelitian ini adalah guru UPTD SD Negeri Genteng 2 yang terdiri dari 7 orang. Rata-rata kemampuan membuat Rencana Pelaksanaan Pembelajaran (RPP) tematik 1 halaman juga masih rendah, belum semua guru membuat persiapan pembelajaran sebelum KBM dilaksanakan. Pelaksanaannya daring melalui zoom milik UPTD SD Negeri Genteng 2.

Data yang diperoleh adalah kemampuan guru dalam membuat Rencana Pelaksanaan Pembelajaran (RPP) tematik 1 halaman. Sedangkan teknik pengumpulan data dengan pedoman observasi dan tugas individu dalam membuat Rencana Pelaksanaan Pembelajaran (RPP) Tematik 1 halaman. Observasi dilakukan untuk mengetahui secara langsung tingkat penguasaan guru dalam membuat Rencana Pelaksanaan Pembelajaran (RPP) tematik di UPTD SD Negeri Genteng 2. Indikator keberhasilan disesuaikan instrumen hasil tugas untuk meningkatkan kemampuan guru dalam membuat Rencana Pelaksanaan Pembelajaran (RPP) tematik 1 halaman.

Setelah diperoleh data selanjutnya dianalisis. Secara garis besar kegiatan analisis data dilakukan dengan langkah-langkah sebagai berikut: 1) menelaah seluruh data yang dikumpulkan., 2) membandingkan seluruh data yang diperoleh dari proses pemberian tindakan pada setiap siklus yang telah dilaksanakan. 3) menyimpulkan hasil analisis data dari beberapa siklus yang telah dilaksanakan. Indikator keberhasilan pelaksanaan siklus diberikan hasil rendah, sedang, dan tinggi dengan data kuantitatif, 1, 2, dan 3 sebagai dasar atau penentu dengan pembulatan 0,5 dibulatkan ke 1. Siklus dihentikan jika $75 \%$ guru sudah berkategori tinggi.

Partisipan dalam penelitian ini melibatkan guru dan pengawas UPTD SD Negeri Genteng 2 sebagai langkah bersama dalam pengembangan mutu pendidikan di sekolah. Di samping itu juga disiapkan dosen dari perguruan tinggi apabila terjadi permasalahan yang sulit untuk dipecahakan sebagai langkah penyelesaian. Jika tidak terjadi permasalahan maka hanya melibatkan kolaborator dari unsur pengawas sebagai pembina di lingkup kecamatan .

\section{HASIL DAN PEMBAHASAN}

Penelitian tindakan sekolah yang telah dilakukan mengalami 2 kali siklus tindakan dan dinyatakan berhasil meningkatkan kemampuan guru dalam membuat Rencana Pelaksanaan Pembelajaran (RPP) Tematik di UPTD SD Negeri Genteng 2. Masingmasing siklus dilaksanakan 2 kali pertemuan. Kegiatan pertemuan masing-masing siklus meliputi pertemuan pertama pelaksanaan workshop daring dan pertemuan kedua tugas 
pembuatan Rencana Pelaksanaan Pembelajaran (RPP) tematik 1 halaman. Waktu kegiatan pada bulan Maret-April 2021.

Adapun tindakan yang telah dilaksanakan dalam 2 siklus dengan 2 kali pertemuan tersebut sebagai berikut.

\section{Siklus I pertemuan 1.}

Perencanaan (Planning)

a. Menyusun rencana kegiatan pertemuan secara daring dan pembinaan dengan semua guru melalui workshop daring di UPTD SD Negeri Genteng 2 tentang membuat Rencana Pelaksanaan Pembelajaran (RPP) tematik 1 halaman.

b. Menyiapkan alat dan sumber belajar, termasuk menyiapkan platform pertemuan virtual.

c. Menyiapkan format penugasan pembeuatan Rencana Pelaksanaan Pembelajaran (RPP) tematik 1 halaman serta pedoman wawancara tentang pelaksanaan workshop daring.

Tindakan (Action)

a. Melaksanakan proses pertemuan secara virtual dan pembinaan sesuai rencana.

b. Menerapkan model pembinaan workshop tentang membuat Rencana Pelaksanaan Pembelajaran (RPP) tematik 1 halaman dengan variasi jigsaw dengan langkah-langkah sebagai berikut. 1) membentuk kelompok workshop menjadi 2 kelompok yang terdiri dari 3 guru untuk kelompok pertama dan 4 guru untuk kelompok kedua dengan kondisi hiterogen, 2). Masing-masing kelompok ada yang mahir membuat Rencana Pelaksanaan Pembelajaran (RPP) tematik 1 halaman dan ada yang kurang mengerti, 3). Dipilih satu orang dari masing-masing kelompok yang sudah mengerti tentang Rencana Pelaksanaan Pembelajaran (RPP) tematik 1 halaman sebagai kelompok ahli, 4). Kelompok ahli berkumpul untuk berdiskusi materi pembuatan Rencana Pelaksanaan Pembelajaran (RPP) tematik 1 halaman sesuai langkah-langkah dalam kurikulum 2013, 5). Kelompok ahli kembali ke kelompoknya untuk membelajarkan langkah-langkah pembuatan Rencana Pelaksanaan Pembelajaran (RPP) tematik 1 halaman yang telah dibahas.

c. Memberikan tugas kepada guru di tiap-tiap kelompok.

Pengamatan (Observation)

a. Mengamati kegiatan guru selama pelaksanaan workshop daring.

Refleksi (Reflection)

a. Melakukan evaluasi tindakan (action evaluation) yang telah dilakukan.

\section{Siklus I pertemuan 2.}

Siklus I pertemuan 2 dilakukan tugas pembuatan Rencana Pelaksanaan Pembelajaran (RPP) tematik oleh masing-masing guru. Setiap guru diberikan kesempatan untuk mengikuti tes secara individu. Pelaksanaan tugas meliputi langkah-langkah dalam pembuatan serta hasilnya. Masing-masing tugas diberikan hasil rendah, sedang, dan tinggi dengan data kuantitatif, 1, 2, dan 3 sebagai dasar atau penentu indikator keberhasilan pelaksanaan siklus agar lebih mudah.

\section{Siklus II pertemuan 1.}

Perencanaan (Planning) 
a. Menyusun rencana kegiatan pertemuan dan pembinaan dengan semua guru melalui workshop daring di UPTD SD Negeri Genteng 2 tentang pembuatan Rencana Pelaksanaan Pembelajaran (RPP) tematik 1 halaman.

b. Menyiapkan alat dan sumber belajar, termasuk menyiapkan platform pertemuan virtual.

c. Menyiapkan format tugas pembuatan Rencana Pelaksanaan Pembelajaran (RPP) tematik 1 halaman serta pedoman wawancara tentang pelaksanaan workshop.

Tindakan (Action)

a. Melaksanakan proses pertemuan dan pembinaan sesuai rencana.

b. Menerapkan model pembinaan workshop tentang pembuatan Rencana Pelaksanaan Pembelajaran (RPP) tematik dengan variasi jigsaw dengan langkah-langkah sebagai berikut. 1) membentuk kelompok workshop menjadi 2 kelompok yang terdiri dari 3 guru untuk kelompok pertama dan 4 guru untuk kelompok kedua dengan kondisi hiterogen, 2). Masing-masing kelompok ada yang mahir membuat Rencana Pelaksanaan Pembelajaran (RPP) tematik dan ada yang kurang mengerti, 3). Dipilih satu orang dari masing-masing kelompok yang sudah mengerti tentang pembuatan Rencana Pelaksanaan Pembelajaran (RPP) tematik 1 halaman sebagai kelompok ahli, 4). Kelompok ahli berkumpul untuk berdiskusi materi pembuatan Rencana Pelaksanaan Pembelajaran (RPP) tematik sesuai kurikulum 2013 serta membahas segala permasalahan yang ada, 5). Kelompok ahli kembali ke kelompoknya untuk membelajarkan program pembuatan Rencana Pelaksanaan Pembelajaran (RPP) tematik 1 halaman yang telah dibahas.

c. Memberikan tugas kepada guru di tiap-tiap kelompok.

Pengamatan (Observation)

a. Mengamati kegiatan guru selama pelaksanaan workshop secara daring.

Refleksi (Reflection)

a. Melakukan evaluasi tindakan (action evaluation) yang telah dilakukan

b. Mengevaluasi hasil wawancara

\section{Siklus II pertemuan 2.}

Siklus II pertemuan 2 dilakukan tugas pembuatan Rencana Pelaksanaan Pembelajaran (RPP) tematik 1 halaman oleh masing-masing guru. Setiap guru diberikan kesempatan untuk mengerjakan tugas pembauatan Rencana Pelaksanaan Pembelajaran (RPP) tematik 1 halaman secara individu. Pelaksanaan tugas meliputi proses dan hasil dalam membuat Rencana Pelaksanaan Pembelajaran (RPP) tematik 1 halaman. Masingmasing tugas diberikan hasil rendah, sedang, dan tinggi dengan data kuantitatif, 1, 2, dan 3 sebagai dasar atau penentu indikator keberhasilan pelaksanaan siklus.

Sesuai dengan rumusan masalah bagaimanakah kemampuan guru dalam membuat Rencana Pelaksanaan Pembelajaran (RPP) tematik 1 halaman dapat ditingkatkan melalui workshop daring dengan variasi model jigsaw di UPTD SD Negeri Genteng 2? Siklus I akan menjadi dasar atau pedoman untuk melaksanakan siklus II. Dalam pelaksanaan siklus I dilakukan tugas masing-masing guru tentang pembuatan Rencana Pelaksanaan Pembelajaran (RPP) tematik 1 halaman terutama pada pertemuan ke 2. Tugas meliputi proses dalam membuat Rencana Pelaksanaan Pembelajaran (RPP) tematik 1 halaman sesuai langkah-langkah dan lihat hasil komponen Rencana Pelaksanaan Pembelajaran (RPP). Disampng itu tugas juga dilihat pendekatan saintifik apakah sudah tampak serta 
tematik yang ada. Adapun secara rinci hasil pelaksanaan workshop daring variasi jigsaw pada siklus I untuk meningkatkan kemampuan guru dalam membuat Rencana Pelaksanaan Pembelajaran (RPP) tematik 1 halaman seperti pada Tabel 1.

Tabel 1. Rekapitulasi Hasil Tugas Kemampuan Guru dalam Membuat RPP Tematik Siklus I Bagi Guru UPTD SD Negeri Genteng 2.

\begin{tabular}{|c|c|c|c|c|c|c|}
\hline \multirow[b]{2}{*}{$\begin{array}{l}\mathbf{N} \\
\mathbf{0}\end{array}$} & \multirow[b]{2}{*}{ Nama } & \multirow[b]{2}{*}{ Jabatan } & \multicolumn{2}{|c|}{ Hasil Tugas } & \multirow[b]{2}{*}{$\begin{array}{l}\text { Rata- } \\
\text { rata }\end{array}$} & \multirow[b]{2}{*}{ Ket } \\
\hline & & & $\begin{array}{c}\text { Komponen } \\
\text { RPP }\end{array}$ & $\begin{array}{l}\text { Tematik/ } \\
\text { Saintifik }\end{array}$ & & \\
\hline 1 & Eka Purwatiningsih & Guru Kelas I & 2 & 2 & 2 & Sedang \\
\hline 2 & Khoiriyah & Guru Kelas II & 2 & 3 & 2,5 & Tinggi \\
\hline 3 & Hendra Prata & Guru Kelas III & 1 & 1 & 1 & Rendah \\
\hline 4 & M. Syukkur & Guru Kelas IV & 3 & 3 & 3 & Tinggi \\
\hline 5 & Erlin Handayani & Guru Kelas V & 1 & 1 & 1 & Rendah \\
\hline 6 & Riski Fitria, Y. & Guru Kelas VI & 1 & 1 & 1 & Rendah \\
\hline \multirow[t]{6}{*}{7} & Moh. Nasruddin & Guru Agama Kelas I-VI & 2 & 2 & 2 & Sedang \\
\hline & Jumlah & & 12 & 13 & 13,5 & \\
\hline & Rata-Rata & & 1,7 & 1,8 & 1,9 & \\
\hline & 3 guru atau $42,86 \%$ & rkategori rendah & & & & \\
\hline & 2 guru atau $28,57 \%$ & rkategori sedang & & & & \\
\hline & 2 guru atau $28,57 \%$ & rkategori tinggi & & & & \\
\hline
\end{tabular}

Berdasarkan data pada siklus I diketahui kemampuan guru dalam membuat Rencana Pelaksanaan Pembelajaran (RPP) tematik 1 halaman yang berkategori tinggi hanya 2 guru dari 7 atau 28,57\%. Oleh sebab itu sesuai indikator keberhasilan $75 \%$ kemampuan guru secara klasikal berkategori tinggi maka siklus dilanjutkan.

Berdasarkan refleksi siklus I langkah selanjutnya dilaksanakan siklus II didasarkan pembentukan kelompok yang lebih representatif. Di samping itu pembimbingan secara intensif juga dilakukan khususnya bagi kelompok ahli. Pembentukan kelompok menjaga hiterogenitas khususnya yang sudah mahir dalam membuat Rencana Pelaksanaan Pembelajaran (RPP) tematik 1 halaman dengan saintifik dipadukan yang sama sekali belum paham dan belum pernah membuat Rencana Pelaksanaan Pembelajaran (RPP) tematik 1 halaman. Pelaksanaan siklus II terdiri dari dua pertemuan dengan rincian pertemuan pertama pemberian materi sedangkan pertemuan kedua pelaksanaan tugas secara individu pada semua guru di UPTD SD Negeri Genteng 2. Setelah pertemuan kedua siklus II dilakukan tugas pembuatan Rencana Pelaksanaan Pembelajaran (RPP) tematik 1 halaman dengan pendekatan saintifik diperoleh hasil sesuai dengan Tabel 2.

Tabel 2 Rekapitulasi Hasil Tugas Kemampuan Guru dalam Membuat RPP Tematik 1 Halaman Siklus II Bagi Guru UPTD SD Negeri Genteng 2.

\begin{tabular}{|c|c|c|c|c|c|c|}
\hline \multirow[b]{2}{*}{$\begin{array}{l}\mathbf{N} \\
\mathbf{0}\end{array}$} & \multirow[b]{2}{*}{ Nama } & \multirow[b]{2}{*}{ Jabatan } & \multicolumn{2}{|c|}{ Hasil Tugas } & \multirow[b]{2}{*}{$\begin{array}{l}\text { Rata- } \\
\text { rata }\end{array}$} & \multirow[b]{2}{*}{ Ket } \\
\hline & & & $\begin{array}{c}\text { Komponen } \\
\text { RPP }\end{array}$ & $\begin{array}{l}\text { Tematik/ } \\
\text { Saintifik }\end{array}$ & & \\
\hline 1 & Eka Purwatiningsih & Guru Kelas I & 3 & 2 & 2,5 & Tinggi \\
\hline 2 & Khoiriyah & Guru Kelas II & 3 & 3 & 3 & Tinggi \\
\hline 3 & Hendra Prata & Guru Kelas III & 2 & 2 & 2 & Sedang \\
\hline 4 & M. Syukkur & Guru Kelas IV & 3 & 3 & 3 & Tinggi \\
\hline
\end{tabular}




\begin{tabular}{|c|c|c|c|c|c|c|}
\hline 5 & Erlin Handayani & Guru Kelas V & 3 & 3 & 3 & Tinggi \\
\hline 6 & Riski Fitria, Y. & Guru Kelas VI & 3 & 3 & 3 & Tinggi \\
\hline 7 & Moh. Nasruddin & Guru Agama Kelas I-VI & 3 & 3 & 3 & Tinggi \\
\hline & Jumlah & & 20 & 19 & 19,5 & \\
\hline & Rata-Rata & & 2,9 & 2,7 & 2,8 & \\
\hline & \multicolumn{6}{|c|}{ Tidak ada guru yang berkategori rendah } \\
\hline & \multicolumn{6}{|c|}{1 guru atau $14,28 \%$ berkategori sedang } \\
\hline & \multicolumn{6}{|c|}{6 guru atau $85,71 \%$ berkategori tinggi } \\
\hline
\end{tabular}

Berdasarkan pelaksanaan siklus II menunjukkan adanya peningkatan kemampuan membuat Rencana Pelaksanaan Pembelajaran (RPP) tematik bagi guru di UPTD SD Negeri Genteng 2. Hal ini dibuktikan terdapat 6 dari 7 guru berdasarkan hasil penugasan diperoleh kemampuan membuat Rencana Pelaksanaan Pembelajaran (RPP) tematik 1 halaman berkategori tinggi. Persentase jumlah guru yang berkategori tinggi adalah $86 \%$. Oleh sebab itu siklus dihentikan sebab sudah sesuai indikator keberhasilan yang diharapkan, yaitu $75 \%$ guru berkategori tinggi.

\section{Pembahasan}

Berdasarkan rumusan masalah ditentukan bahwa kemampuan guru dalam membuat Rencana Pelaksanaan Pembelajaran (RPP) tematik 1 halaman untuk pembelajaran dapat ditingkatkan melalui workshop daring dengan variasi model jigsaw di UPTD SD Negeri Genteng 2. Hal ini dibuktikan dalam pelaksanaan penelitian tindakan sekolah yang terdiri dari 2 siklus menunjukkan pada siklus I setelah dilakukan workshop daring dengan variasi model jigsaw untuk meningkatkkan kemampuan guru membuat Rencana Pelaksanaan Pembelajaran (RPP) tematik 1 halaman di UPTD SD Negeri Genteng 2 berdasarkan hasil penugasan diperoleh, dari 7 guru, terdapat 3 guru atau 42,86\% berkategori rendah, 2 guru atau 28,57\% berkategori sedang, dan 2 guru atau 28,57\% berkategori tinggi.

Keadaan ini harus dilanjutkan pada siklus II, sebab belum mencapai indikator keberhasilan yang diharapkan, yaitu $75 \%$ berkategori tinggi. Setelah dilaksanakan siklus II diperoleh data kemampuan guru di UPTD SD Negeri Genteng 2 dalam membuat Rencana Pelaksanaan Pembelajaran (RPP) tematik 1 halaman sebagai berikut: Dari 7 guru tidak terdapat guru yang berkategori rendah, 1 guru atau 14,28\% berkategori sedang, dan 6 guru atau 85,71\% berkategori tinggi. Oleh sebab itu siklus dihentikan, sebab sudah mencapai indikator keberhasilan yang diharapkan, yaitu $75 \%$ berkategori tinggi.

Hal ini menunjukkan workshop daring variasi model jigsaw dapat meningkatkan kemampuan guru dalam membuat Rencana Pelaksanaan Pembelajaran (RPP) tematik 1 halaman untuk pembelajaran. Sebab jigsaw menyebabkan guru dapat aktif. Hal ini didasarkan bahasan teori sebelumnya berdasarkan pendapat Anas ${ }^{14}$ tentang jenis-jenis workshop yang dapat divariasi Jigsaw adalah tipe pembelajaran kooperatif yang dikembangkan oleh Elliot Aronson's. Model pembelajaran ini didesain untuk meningkatkan rasa tanggung jawab siswa terhadap pembelajarannya sendiri dan juga pembelajaran orang lain. Siswa dalam hal ini adalah guru tidak hanya mempelajari materi yang diberikan, tetapi mereka juga harus siap memberikan dan mengajarkan materi

\footnotetext{
${ }^{14}$ Anas, "Workshop Dan Jenisnya," $\quad$ Makalah $\quad$ (Online), http://anasaff.blogspot.com/2012/08/workshop-dan-jenisnya.html.
} 
tersebut kepada kelompoknya. Sehingga baik kemampuan secara kognitif maupun sosial sangat diperlukan.

Jigsaw menggabungkan konsep pengajaran pada teman sekelompok atau sebaya dalam usaha membantu belajar. Jigsaw didesain untuk meningkatkan rasa tanggung jawab untuk pembelajarannya sendiri dan juga pembelajaran orang lain. Dalam penerapan jigsaw, peserta diklat dibagi berkelompok dengan lima atau enam anggota kelompok belajar heterogen. Setiap anggota bertanggung jawab untuk mempelajari, menguasai bagian tertentu bahan yang diberikan kemudian menjelaskan pada anggota kelompoknya. Dengan demikian terdapat rasa saling membutuhkan dan harus bekerjasama secara kooperatif untuk mempelajari materi yang ditugaskan. Para anggota dari kelompok lain yang bertugas mendapat topik yang sama berkumpul dan berdiskusi tentang topik tersebut. Kelompok ini disebut kelompok ahli. Kemudian anggota tim ahli kembali ke kelompok asal dan mengajarkan apa yang telah dipelajarinya dan didiskusikan di dalam kelompok ahlinya untuk diajarkan kepada anggota kelompoknya sendiri.

Sedangkan workshop sebagai salah satu metode pembinaan yang efektif dan dapat digunakan oleh kepala sekolah maupun pengawas sebagaimana pernyataan Dharma ${ }^{15}$ bahwa kemampuan penguasaan teknologi informasi dan komunikasi bagi guru dapat ditingkatkan melalui workshop, sebab workshop sebagai salah satu metode yang dapat digunakan untuk melakukan pembinaan bagi guru oleh kepala sekolah.

Di masa pandemi covid-19, semua kegiatan yang berpotensi kerumunan masa dilarang. Sehingga workshop ini dilaksanakan secara daring/virtual, namun esensi dari workshop daring tidak mengurangi workshop tatap muka. Workshop daring memberi ruang kepada para guru untuk belajar Rencana Pelaksanaan Pembelajaran (RPP) sekaligus belajar teknologi pembelajaran. Dua kelompok yang telah dibentuk pada awal pertemuan virtual dipecah dalam zoom kelompok mereka masing-masing. Mereka bisa memakai zoom gratis /tidak berbayar meskipun harus beberapa kali mengalami kendala dan mati ditengah sedang berdiskusi.

Model pembelajaran Jigsaw ini dilandasi oleh teori belajar humanistik, karena teori belajar humanistik menjelaskan bahwa pada hakekatnya setiap manusia adalah unik, memiliki potensi individual dan dorongan internal untuk berkembang dan menentukan perilakunya. $^{16}$

Kemampuan guru dalam membuat Rencana Pelaksanaan Pembelajaran (RPP) tematik 1 halaman dapat meningkat dengan workshop variasi jigsaw sebab seknik mengajar jigsaw sebagai model pembelajaran kooperatif bisa digunakan dalam berbagai permasalahan dan berbagai tingkatan. Model pembelajaran kooperatif tipe jigsaw merupakan model pembelajaran kooperatif, peserta didik belajar dalam kelompok kecil yang terdiri dari 3-4 orang dengan memperhatikan keheterogenan, bekerjasama positif dan setiap anggota bertanggung jawab untuk mempelajari masalah tertentu dari materi yang diberikan dan menyampaikan materi tersebut kepada anggota kelompok yang lain.

Kunci tipe Jigsaw ini adalah interdependence setiap peserta terhadap anggota tim yang memberikan informasi yang diperlukan. Artinya para peserta didik dalam hal ini

\footnotetext{
${ }^{15}$ Surya Dharma, Identifikasi Masalah Kepengawasan; Modul Untuk Pengawas (Jakarta: Ditjen PMPTK, 2008).

${ }^{16}$ Arfiyadi, "Model- Model Pembelajaran $\quad$ Kooperatif," 2012, http://modelpembelajarankooperatif.blogspot.co.id/2012/08/jigsaw.html.
} 
guru harus memiliki tanggung jawab dan kerja sama yang positif dan saling ketergantungan untuk mendapatkan informasi dan memecahkan masalah yang diberikan.

Kemampuan guru dalam Rencana Pelaksanaan Pembelajaran (RPP) Tematik 1 halaman adalah kemampuan yang bersifat aplikatif artinya tidak perlu untuk teori yang terlalu banyak. Oleh sebab itu guru dituntut untuk dapat melakukannya. Kegiatan workshop daring sebagai upaya yang dapat dilakukan guru secara langsung mempraktekkan kemampuan membuat Rencana Pelaksanaan Pembelajaran (RPP) tematik 1 halaman. Bimbingan teman sejawat sangat efektif ketika terbentuk kelompok dengan menggunakan variasi jigsaw, sebab ada beberapa guru yang sudah ahli dalam satu kelompok dapat memberikan bimbingan secara langsung, sehingga hasilnya akan lebih baik. Hasil penelitian terdahulu Harsono ${ }^{17}$ menyebutkan kegiatan workshop dengan menggunakan variasi jigsaw dapat meningkatkan kemampuan ICT guru di Guslah 3 Konang Tahun 2015 dibuktikan terdiri dari 2 siklus menunjukkan pada siklus I setelah dilakukan workshop dengan variasi model jigsaw untuk meningkatkkan kemampuan TIK guru di guslah 3 Konang berdasarkan hasil tes diperoleh dari 30 guru, 8 guru atau 26,67\% berkategori rendah, 11 guru atau 36,67\% berkategori sedang, dan 11 guru atau 36,67\% berkategori tinggi. Setelah dilanjutkan pada siklus II mengalami kenaikan, yaitu dari 30 guru terdapat 2 guru atau 6,67\% berkategori rendah, 6 guru atau $20 \%$ berkategori sedang, dan 22 guru atau $73,33 \%$ berkategori tinggi sehingga sudah mencapai indikator keberhasilan yang diharapkan, yaitu $70 \%$.

\section{KESIMPULAN}

Berdasarkan pelaksanaan penelitian tindakan sekolah di UPTD SD Negeri Genteng 2 sesuai dengan rumusan masalah dan tujuan penelitian disimpulkan bahwa kemampuan guru dalam membuat Rencana Pelaksanaan Pembelajaran (RPP) tematik 1 halaman dapat ditingkatkan melalui workshop daring dengan variasi model jigsaw. Hal ini dibuktikan dalam pelaksanaan penelitian tindakan sekolah yang terdiri dari 2 siklus menunjukkan adanya kenaikan dari siklus I ke siklus II berdasarkan hasil penugasan yang dilakukan dalam pembuatan Rencana Pelaksanaan Pembelajaran (RPP) tematik 1 halaman, yaitu dari 7 guru terdapat 3 guru atau $42,86 \%$ berkategori rendah, 2 guru atau 28,57\% berkategori sedang, dan 2 guru atau $28,57 \%$ berkategori tinggi. Setelah dilaksanakan siklus II diperoleh data kemampuan guru UPTD SD Negeri Genteng 2 dalam membuat Rencana Pelaksanaan Pembelajaran (RPP) tematik 1 halaman sebagai berikut: dari 7 guru tidak terdapat guru yang berkategori rendah, 1 guru atau $14,28 \%$ berkategori sedang, dan 6 guru atau 85,71\% berkategori tinggi, oleh sebab itu siklus dihentikan, sebab sudah mencapai indikator keberhasilan yang diharapkan, yaitu melebihi $75 \%$ berkategori tinggi.

Setelah mengkaji dan melakukan penelitian tindakan sekolah dengan menerapkan workshop daring dengan variasi model jigsaw sesuai kesimpulan di atas diberikan saran kepada guru sesuai dengan manfaat penelitan hendaknya bapak dan ibu guru terus meningkatkan kompetensinya dalam membuat Rencana Pelaksanaan Pembelajaran (RPP) khususnya tematik 1 halaman dengan pendekatan saintifik sebab saat ini sudah mulai diberlakukan pada kurikulum 2013.

\footnotetext{
${ }^{17 H a r s o n o, ~ " U p a y a ~ M e n i n g k a t k a n ~ K e m a m p u a n ~ G u r u ~ D a l a m ~ P e n g g u n a a n ~ T e k n o l o g i ~ I n f o r m a s i ~ D a n ~}$ Komunikasi (TIK) Untuk Pembelajaran Melalui Workshop Dengan Variasi Model Jigsaw Di Guslah 3 Kecamatan Konang Kabupaten Bangkalan.”
} 


\section{DAFTAR PUSTAKA}

Anas. "Workshop Dan Jenisnya." Makalah (Online), 2012. http://anasaff.blogspot.com/2012/08/workshop-dan-jenisnya.html.

Anngi St Anggari, Afriki, Dara Retno dkk. Peduli Terhadap Makhluk Hidup. Buku Tematik Terpadu Siswa Kelas IV. Edisi Revisi 2016. Jakarta: Kemendikbud, 2016.

Arfiyadi. "Model- Model Pembelajaran Kooperatif," 2012. http://modelpembelajarankooperatif.blogspot.co.id/2012/08/jigsaw.html.

Darmadi, Hamid. Metode Penelitian Pendidikan. Bandung: Alfabeta, 2011.

Dharma, Surya. Identifikasi Masalah Kepengawasan; Modul Untuk Pengawas. Jakarta: Ditjen PMPTK, 2008.

Harsono. "Upaya Meningkatkan Kemampuan Guru Dalam Penggunaan Teknologi Informasi Dan Komunikasi (TIK) Untuk Pembelajaran Melalui Workshop Dengan Variasi Model Jigsaw Di Guslah 3 Kecamatan Konang Kabupaten Bangkalan." Penelitian Tindakan Sekolah Pengawas UPTD Konang Kabupaten Bangkalan. Bangkalan, 2015.

Haryanto. "Model Pembelajaran Kooperatif Tipe Jigsaw." Makalah (Online), 2012. http://belajarpsikologi.com/model-pembelajaran-kooperatif-jigsaw.

Kurikulum 2013 Sekolah Dasar Kementerian Pendidikan dan Kebudayaan.

Lie, Anita. Cooperative Learning:Mempraktikkan Cooperative Learning Di RuangRuang Kelas. Jakarta: Gramedia Widiasarana Indonesia, 2008.

Mashud, Abu. "RPP Satu Halaman/Lembar SD/MI Kelas 1,2,3,4,5 Dan 6." Artikel online, 2020. https://dewanguru.com/2020/01/22/rpp-satu-halaman-lembar-sd-mikelas-12345-dan-6/.

Mubah, Hilmi Qosim. "PSIKOMANAJERIAL PERSONALIA PENDIDIKAN; MENGKONSTRUKSI PRODUKTIVITAS KERJA PERSPREKTIF IDENTIFIKASI KEMATANGAN PERSONAL.” AL-FIKRAH: Jurnal Studi Ilmu Pendidikan Dan Keislaman 2, no. 2 (2019). https://www.jurnal.alhamidiyah.ac.id/index.php/al-fikrah/article/view/57.

Muhari. Meningkatkan Kemampuan Guru Kelas V dan VI dalam Menyusun Tes Hasil Belajar Akhir Semester Melalui Workshop di Gugus Sekolah I Kecamatan Kamal Kabupaten Bangkalan Tahun 2013. Penelitian Tindakan Sekolah. Tidak diterbitkan: Pengawas UPTD Pendidikan di Kecamatan Kamal Kabupaten Bangkalan. 2013.

Permendikbud Nomor 22 Tahun 2016 Tentang Standar Proses Pendidikan Dasar dan Menengah

Permendikbud Nomor 160 Tahun 2014 tentang Pemberlakuan kurikulum tahun 2006 dan kurikulum 2013.

Sadiman, Rahardjo, Haryono, Raharjito. Media Pendidikan Pengertian, Pengembangan dan Pemanfaatannya. Bandung: Tarsito, 2010

Sardiman. Interaksi Dan Motivasi Belajar Mengajar. Jakarta: Rajawali Pers, 2014.

Silberman, Melvin L. Active Learning 101 Stategi Pembelajarn Aktif. Yogyakarta: Yappendis, 2002.

Wahidmurni. "RENCANA PELAKSANAAN PEMBELAJARAN: RPP 1 LEMBAR." Malang, 2019. http://repository.uin-malang.ac.id/5377/1/5377.pdf.

Tim Dirjend PMPTK. Penelitian Tindakan Sekolah. Bahan Belajar Mandiri Kelompok Kerja Pengawas Sekolah. Jakarta: Ditjend PMPTK, 2009.

Undang - Undang RI No 20 Tahun 2003 tentang Sisdiknas. 
Yusuf, Mohammad. "PENINGKATAN KEMAMPUAN GURU DALAM MENENTUKAN KRITERIA KETUNTASAN MINIMAL (KKM) MELALUI WORKSHOP DI UPTD SDN BANDA SOLEH 1 KECAMATAN KOKOP KABUPATEN BANGKALAN TAHUN 2019." Re-JIEM (Research Journal of Islamic Education Management) 2, no. 1 (2019). https://doi.org/https://doi.org/10.19105/re-jiem.v2i1.2456. 